\title{
Parental Divorce and Maldivian Young Adult Student's Romantic Relationship Quality: Indirect Pathways through Attitude towards Divorce
}

Aishath Shanoora, Hanina H. Hamsan, Haslinda Abdullah \& Azlina Mohd. Khir

To Link this Article: http://dx.doi.org/10.6007/IJARBSS/v11-i19/7420 DOI:10.6007/IJARBSS/v11-i19/7420

Received: 11 October 2021, Revised: 29 October 2021, Accepted: 20 November 2021

Published Online: 25 December 2021

In-Text Citation: (Shanoora et al., 2021)

To Cite this Article: Shanoora, A., Hamsan, H. H., Abdullah, H., \& Khir, A. M. (2021). Parental Divorce and Maldivian Young Adult Student's Romantic Relationship Quality: Indirect Pathways through Attitude towards Divorce. International Journal of Academic Research in Business and Social Sciences, 11(11), 106117.

Copyright: (c) 2021 The Author(s)

Published by Human Resource Management Academic Research Society (www.hrmars.com)

This article is published under the Creative Commons Attribution (CC BY 4.0) license. Anyone may reproduce, distribute, translate and create derivative works of this article (for both commercial and non-commercial purposes), subject to full attribution to the original publication and authors. The full terms of this license may be seen at: http://creativecommons.org/licences/by/4.0/legalcode

Special Issue Title: Youth and Community Wellness, 2021, Pg. $106-117$

Full Terms \& Conditions of access and use can be found at http://hrmars.com/index.php/pages/detail/publication-ethics 


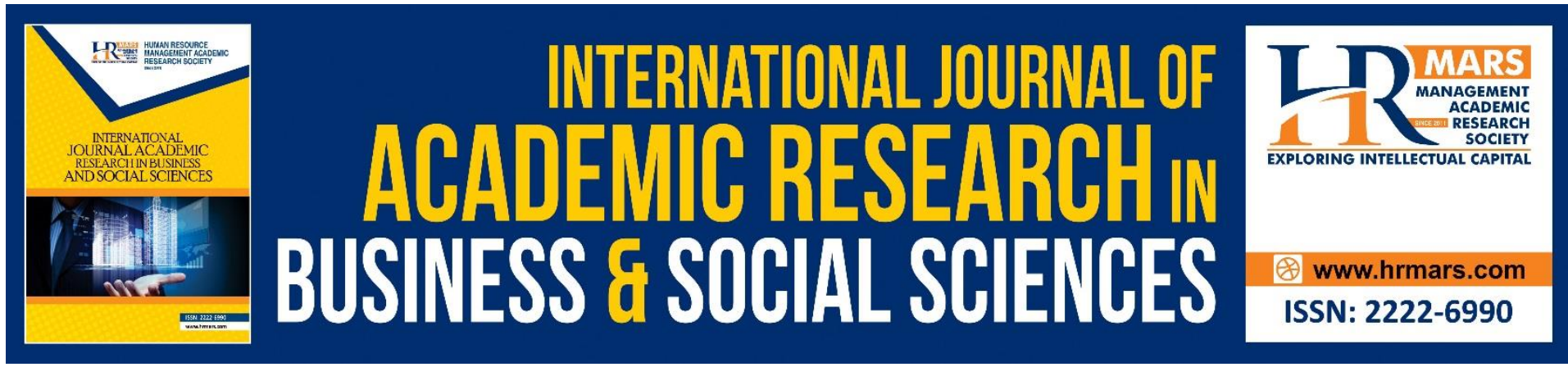

\title{
Parental Divorce and Maldivian Young Adult Student's Romantic Relationship Quality: Indirect Pathways through Attitude towards Divorce
}

\author{
Aishath Shanoora ${ }^{2}$, Hanina H. Hamsan ${ }^{1,2}$, Haslinda Abdullah ${ }^{1,2}$ \\ \& Azlina Mohd. Khir ${ }^{2}$ \\ ${ }^{1}$ Institute for Social Science Studies, Putralnfoport, Universiti Putra Malaysia, 43400 UPM \\ Serdang, Selangor, Malaysia, ${ }^{2}$ Faculty of Human Ecology Manusia, Universiti Putra Malaysia, \\ 43400 UPM Serdang, Selangor, Malaysia \\ Corresponding Author Email: hanina@upm.edu.my
}

\begin{abstract}
This study aimed to identify the mediating roles of attitude towards divorce on the relationship between parental divorce and romantic relationship quality of young adult student's. A total of 463 Maldivian undergraduate students participated as respondents. They were in a romantic relationship, ages 18 to 25. Data was collected using a self-administered questionnaire. Relationship quality were measured using relationship quality component inventory and attitudes towards divorce were measured using attitudes towards divorce scale. Data was analyzed using the PLS-SEM technique. Results revealed that parental divorce was associate with low romantic relationship quality through favorable attitude towards divorce. This will be helpful for professionals as it can be used to identify specific preventive measures to reduce the negative impact of parental divorce. The future study suggest incorporating a larger sample with participants that are more representative of the general population in terms of gender and working population.
\end{abstract}

Keywords: Parental Divorce, Young Adult Students, Mediation, Attitude towards Divorce, PLSSEM

\section{Introduction}

Romantic relationship satisfaction is a good predictor of life satisfaction and overall wellbeing (Adamczyk, 2017). It contributes to the development of positive self-concepts of individuals (Meier \& Allen, 2008). Being able to build and maintain a healthy romantic relationship is associated with better psychological adjustment and overall wellbeing of individuals, On the other hand, having an unhealthy romantic relationship is associated with emotional distress (Yu et al., 2015). Several factors contribute to the development of romantic relationship quality, however, specific characteristics in the family of origin are of importance (Conger et al., 2000; Kumar \& Mattanah, 2018). Family characteristics have been associated with the quality of the romantic relationship of young adults. For example, evidence suggests that parental divorce has destructive effects on young adult's romantic relationship quality (Amato \& Booth, 1991; Lee, 2018). Recent studies have also examined the effect of attitude towards 
divorce on young adult's romantic relationships (Riggio \& Fite, 2006). However, the factors that explain the mechanisms of how parental divorce impacts young adult's romantic relationship quality have been explored in a limited number of studies (Cui, Fincham, \& Durtschi, 2011). This study addresses this issue by investigating the mediating role of attitudes towards divorce on the relationship between parental divorce and young adult's romantic relationship quality.

\section{Divorce in the Maldives}

Previous research has established the impact of parental divorce on young adults; however, this has yet to be explored through a researcher's lens in the Maldives. The Maldives is a $100 \%$ Muslim country with a population of just above 400,000 . Despite the small population, the rate of divorce recorded in the Maldives is extremely high. In fact, in 2002, Maldives was listed in the genius book of world records as the country with the highest number of divorces ("Highest divorce rate ", 2002). The past decades of divorce statistics show an increase in the number of divorces from year to year. For example, in 2006 the divorce rate among Maldivians was recorded as 2100 , and with a gradual increase over the years, it had reached 3500 in 2016, possibly affecting thousands of children every year (Statistical Pocketbook2017, 2017).

\section{Theoretical Perspective}

According to social learning theory, individuals learn behaviors through their observation, imitation, and experiences (Bandura, 1977). This theory also assumes that individuals determine and choose behaviors in any given situation based on the experiences they have had, hence the learned behaviors are likely to influence their future relationships (Gray \& Tallman, 1986). Furthermore, the theory suggests that by observing the behaviors of their parents' relationship, young adults could develop their attitudes toward marriage and divorce. For example, if children view their parents' relationship as low quality, where they observe high levels of conflict before the divorce, they form positive attitudes toward divorce (Cunningham \& Thornton, 2006). Therefore, social learning theory can be used as a guide to explain the influence of parental divorce on romantic relationship quality, through attitudes towards divorce.

\section{Parental Divorce and Young Adult's Romantic Relationship Quality}

The impact of parental divorce has been studied as one of the main family disruptions in society (Emery, 1999; Shansky, 2002). Research on the long-term effect of parental divorce has shown harmful effects on children of divorce including negative impacts on their romantic relationship. Past research has linked parental divorce to relationship quality of young adults (Amato, 1996; Amato \& Kane, 2011; Bartell, 2005; Cui \& Fincham, 2010; Cui et al., 2011; Lee, 2018) and indirect effects of parental divorce through relationships with fathers on daughters' romantic relationships (Lee, 2019). Although the empirical literature on parental divorce and its impact on children have been studied widely, a fairly small amount of studies have focused on the impact of parental divorce on young adult's romantic relationships. Few studies have identified parental divorce as a factor that challenges young adults from divorced families to form and maintain close relationships (Cui et al., 2011; Mustonen et al., 2011). Compared to young adults from intact families, young adults from divorced families have been found to have greater difficulties and face higher risks in their relationship (Amato, 1996; Braithwaite et al., 2016). Young adults from divorced families trust their partners less and are less 
committed to their relationship compared to those from intact families (Jacquet \& Surra, 2001; Whitton et al., 2013). Similarly, children who have experienced parental divorce are uncertain about the possibility of success of the relationship and are very guarded about entering into romantic relationships (Morrison, Fife, \& Hertlein, 2017). They are less satisfied with their partners and view divorce as an easy solution to their problems and their relationships (Rholes et al., 2001).

The limited research on parental divorce and young adult's romantic relationship quality has focused on different aspects of relationship quality separately. However, the overall quality of romantic relationships includes different domains; commitment, love, satisfaction, intimacy, passion, and trust (Fletcher et al., 2000). The existing literature has explored these domains in isolation to determine the quality of the relationship. For example, some of the studies have determined the quality of the relationship based on commitment, while other studies have focused on trust. Hence, in this study we will measure the overall quality of romantic relationships, using the domains identified by Fletcher et al., 2000).

\section{Indirect Pathways Through Attitude towards Divorce}

Due to limited research exploring parental divorce and romantic relationship quality, little is known about the potential mechanisms that link parental divorce to the romantic relationship of young adults. However, few studies have documented that attitude towards divorce mediated the association between parental divorce and romantic relationship quality. Past studies have shown that when compared to children from intact families, children from divorced families hold more negative attitudes about marriage and more positive attitudes towards divorce (Kwan et al., 2013; Moon, 2011). For example, Riggio and Weiser (2008), found an association between parental divorce and low relationship satisfaction, relationship conflict, commitment, the desirability of lower expectations for relational success, and relationship dissolution through attitude towards divorce. Similarly, Cui and Fincham (2010) also found that young adults who possess positive attitudes towards divorce were associated with low commitment to relationship and relationship dissolution.

The limited literature in this area suggests that attitude toward divorce could play an important role in explaining the association between parental divorce and romantic relationship quality. It is important to note that most of the available literature in this area has studied the interactions of these variables in Western families. With the alarming numbers of divorce in the Maldives, it is safe to assume that a fair percentage of Maldivian children will experience parental divorce before they reach the age of 18 . The experiences of the process of their parent's divorce would have shaped their attitudes towards divorce which in turn may impact their adult romantic relationships. Hence, this study extends to investigate a possible mediation effect of attitude towards divorce on the relationship between parental divorce and romantic relationship quality.

The present study sought to investigate the indirect pathways through which parental divorce is associated with young adult's romantic relationship quality. Based on the research reviewed, and informed by social learning theory, we hypothesized that: H1. Favorable attitudes towards divorce will mediate the association between parental divorce and young adult's romantic relationship quality. Individuals who have experienced parental divorce will have more favorable attitudes towards divorce which will in turn be related to low romantic 
relationship quality of young adults, as children form attitudes needed for the later success of their romantic relationships through observations and experiences.

\section{Method}

\section{Participants}

A total of 463 students, between the ages of 18 to 25 years from two universities and four colleges in the Maldives participated in the study. One question "Are you currently in a romantic relationship?" was asked to identify the participant's relationship status. The total participants consisted of $353(76.2 \%)$ females and 110 (23.8\%) males, with a mean age of 21.02 years. Out of the 463 participants, 166 (35.9\%) were in marital relationships while 297(64.1\%) participants were in committed dating relationships.

\section{Data Collection}

A quantitative approach using a self-administered questionnaire was adopted for the study. Multi-stage cluster sampling technique was used to recruit participants for the study. Once, the participants were identified by asking them the above question orally, they were given information about the study and asked to sign in the consent form. Next, they were given a battery of questionnaires that included demographic questions about their parents and themselves, attitude towards divorce scale, and perceived relationship quality component scale. Collected data were then analyzed using IBM Statistical Package for Social Sciences (SPSS) and SmartPLS 3.0 software. SmartPLS software utilizes structural equation modeling of partial least squares. (Hair et al., 2014)

\section{Measures}

Relationship quality was measured using the perceived relationship quality component inventory developed by Fletcher et al (2000). The scale consisted of 18 items measuring 6 components; love, passion, commitment, trust, satisfaction, and intimacy. Some examples of the items include; "how connected are you to your partner?", "How dedicated are you to your relationship?" Participants rated each item on a seven-point Likert scale, ranging from 1 (not at all) to 7 (extremely). A Likert-type scale assumes that the strength or intensity of the experience is linear. A choice of five to seven or even nine pre-coded responses with the neutral point being neither agree nor disagree (McLeod, 2019). This study adopted the established instrument with a seven-point Likert scale. All items from all subscales were averaged to get a total score for relationship quality. Higher scores indicate better quality of the relationship. The alpha coefficient for the scale was 0.88 .

Attitude toward divorce. A scale developed and used by Kinnaird and Gerrard (1986) was used to measure attitude towards divorce. The scale required respondents to rate favorable and unfavorable attitudes towards divorce on a Likert scale ranging from 1 (not at all) to 5 (very much). For example, "many people who get divorced are too weak to make personal sacrifices for the good of their families". The alpha coefficient for the scale was.79. All items were averaged and higher scores indicate more favorable attitudes toward divorce.

Demographics. Participants were asked to indicate their age, gender, their relationship status, and parents' marital status before the participants turned 18 (response for parental marital status were coded as $0=$ married and $1=$ divorced). 


\section{Results}

\section{Descriptive Statistics}

Table 1 depicts the demographic characteristics of parental divorce. It provides a comparison of means of the variables between intact and divorce parents and the total sample. Compared to young adults from intact families, young adults from divorced families reported lower levels of relationship quality. Furthermore, attitudes towards divorce are slightly higher in divorced families compared to intact families.

Table 1. Demographic characteristics by parental divorce

\begin{tabular}{llll}
\hline variables & $\begin{array}{l}\text { Intact } \\
(\mathrm{N}=64)\end{array}$ & $\begin{array}{l}\text { Divorced } \\
(\mathrm{N}=399)\end{array}$ & $\begin{array}{l}\text { Total } \\
(\mathrm{N}=463)\end{array}$ \\
\hline Relationship Quality (RQ) & $3.21(1.13)$ & $1.92(1.03)$ & $2.0(1.14)$ \\
Attitude towards divorce (ATTD) & $3.59(1.18)$ & $3.96(1.09)$ & $3.92(1.11)$ \\
\hline
\end{tabular}

Note: The ranges of the variables; perceived relationship quality: Low (1-3.5) and high (3.6-7), attitude towards divorce: unfavorable (1- 2.5), favorable (2.6-5). Values outside the parentheses are the mean for the variables and inside the parenthesis are standard deviations.

\section{Measurement Model}

Before the analysis of the structural model, we analyzed the measurement model. Table 2 shows the construct reliability and convergent validity for all the variables in this study. The composite reliability values of 0.957 (RQ), and 0.965 (ATTD) demonstrate high levels of internal consistency of these constructs.

Table 2: Internal consistency and convergent validity

\begin{tabular}{|c|c|c|c|c|}
\hline Construct & Items & Loading & CR & AVE \\
\hline \multirow[t]{6}{*}{ Relationship Quality (RQ) } & Commitment & 0.899 & 0.957 & 0.788 \\
\hline & Intimacy & 0.920 & & \\
\hline & Love & 0.907 & & \\
\hline & Passion & 0.835 & & \\
\hline & Satisfaction & 0.956 & & \\
\hline & Trust & 0.801 & & \\
\hline \multirow[t]{12}{*}{ Attitude towards Divorce (ATTD) } & ATT1 & 0.840 & 0.965 & 0.695 \\
\hline & ATT2 & 0.814 & & \\
\hline & ATT3 & 0.835 & & \\
\hline & ATT4 & 0.868 & & \\
\hline & AAT5 & 0.872 & & \\
\hline & ATT6 & 0.844 & & \\
\hline & ATT7 & 0.816 & & \\
\hline & ATT8 & 0.812 & & \\
\hline & ATT9 & 0.841 & & \\
\hline & ATT10 & 0.835 & & \\
\hline & ATT11 & 0.801 & & \\
\hline & ATT12 & 0.820 & & \\
\hline Parental Divorce (PD) & PMS1 & 1.000 & 1.000 & 1.000 \\
\hline
\end{tabular}


Similarly, all the constructs achieve a minimum threshold value of 0.5 for average variance extracted ( $A V E$ ) demonstrating good convergent validity, indicating that more than $50 \%$ of the constructs variance is explained by the items (Hair et al., 2014). The assessment of discriminant validity using the Fornell and Larcker (1981) criterion as well as the HTMT criterion (Henseler, Ringle, \& Sarstedt, 2015) is represented in Tables 3 and 4.

Table 3. Fornell and Larcker Criterion

\begin{tabular}{llll}
\hline & ATTD & PD & RQ \\
\hline ATTD & $\mathbf{0 . 8 3 3}$ & & \\
PD & 0.698 & $\mathbf{1}$ & \\
RQ & -0.487 & -0.394 & $\mathbf{0 . 8 8 8}$ \\
\hline
\end{tabular}

Notes: Diagonal elements represent the square root of AVE. Off diagonal elements are simple bivariate correlations between the constructs

Table 4. HTMT criterion

\begin{tabular}{llll}
\hline & ATTD & PD & RQ \\
\hline ATTD & & & \\
PD & 0.708 & & \\
RQ & 0.509 & 0.403 & - \\
\hline
\end{tabular}

Note. Criteria: discriminant validity is established at $\mathrm{HTMT}_{0.85}$,

As seen in table 3 , the square roots of AVE of each construct are larger than the estimated correlation of the construct, indicating that all constructs are different from one another. Hence, it can be implied that each construct captures the phenomenon unique to them and are not represented by other constructs in the model (Hair et al., 2014). Furthermore, the values of the correlation of the respective constructs do not violate the most conservative $\mathrm{HTMT}_{0.85}$ criterion (refer to Table 4 ) for assessing discriminant validity (Henseler et al., 2015).

\section{Structural Model - Hypothesis Testing}

Before assessing the structural model, it was tested for collinearity issues. The variance inflated factor (VIF) value for all constructs was lower than the threshold value of 3.3 (Diamantopoulos \& Siguaw, 2006), suggesting there were no collinearity issues. Before exploring the hypothesized indirect relationships, direct relationships of the variables were checked. Table 5 illustrates the direct relationships of the variables.

Table 5. Direct relationships

\begin{tabular}{llllll}
\hline Relationship & $\begin{array}{l}\text { Direct effect } \\
(\text { ( ) }\end{array}$ & $\begin{array}{l}\text { Std.Error } \\
(\mathrm{SE})\end{array}$ & T-Statistics & P Values & $\begin{array}{l}\text { Relationship } \\
\text { Established }\end{array}$ \\
\hline PD $\rightarrow$ RQ & -0.104 & 0.089 & 1.117 & 0.120 & No \\
PD $\rightarrow$ ATTD & 0.698 & 0.037 & $19.107^{* *}$ & 0.000 & Yes \\
ATTD $\rightarrow$ RQ & -0.415 & 0.083 & $4.979^{* *}$ & 0.000 & Yes \\
\hline
\end{tabular}

Notes. ${ }^{*} \mathrm{p}<0.05, * * \mathrm{p}<0.01$ (one-tailed),

According to table 5 parental divorce was associated with attitudes toward divorce, (PD $\rightarrow$ ATTD, $\beta=0.698, t=19.107)$, and attitude towards divorce was associated with 
relationship quality (ATTD $\rightarrow R Q, \beta=-0.415, t=4.979$ ). However, Parental divorce did not have a significant association with relationship quality $(P D \rightarrow R Q, \beta=-0.104, t=1.117)$.

Table 6. Indirect relationships

\begin{tabular}{llllllll}
\hline Relationship & $\begin{array}{l}\text { Indirect } \\
\text { effect } \\
(\beta)\end{array}$ & $\begin{array}{l}\text { Std.Err } \\
\text { or }(\mathrm{SE})\end{array}$ & t-value & p-value & Decision & 2.5 & 97.5 \\
& & & & & $\mathrm{LL}$ & $\mathrm{UL}$ \\
\hline $\mathrm{PD} \rightarrow$ ATTD $\rightarrow \mathrm{RQ}$ & -0.289 & 0.060 & $4.792^{* *}$ & 0.000 & supported & -0.411 & -0.173 \\
& & & & & & &
\end{tabular}

Notes. ${ }^{* *} p<0.01$ (two-tailed),

Table 6 depicts results for the hypothesized indirect relationship, which was found significant at a 99 percent confidence interval (PD $\rightarrow$ ATTD $\rightarrow R Q, \beta=-0.289, t=4.792$ ). Besides, the bootstrap confidence intervals values for the hypothesis did not straddle a zero between the lower and the upper intervals. Hence, it was concluded that attitude towards divorce mediated the association between parental divorce and relationship quality of young adults.

Table 7. Determination of coefficient $\left(R^{2}\right)$, effect size $\left(f^{2}\right)$, and predictive relevance $\left(Q^{2}\right)$

\begin{tabular}{llcll}
\hline & $\begin{array}{l}\text { Co-efficient } \\
\text { determination }\end{array}$ & of & Predictive relevance & Effect size $\left(f^{2}\right)$ \\
\hline RQ & $\mathrm{R}^{2}$ & $\mathrm{Q}^{2}$ & RQ & Effect Size \\
ATTD & 0.240 & 0.188 & & \\
PD & & & 0.117 & Small \\
\hline
\end{tabular}

Finally, the model was tested for coefficient of determination $\left(R^{2}\right)$, the effect size $\left(f^{2}\right)$, and the predictive relevance $\left(Q^{2}\right)$ of exogenous variables on the endogenous variable. As seen from table 7 , the results showed that $R^{2}$ was 0.240 , suggesting that the exogenous variables in the study, which were parental divorce and attitude towards divorce explain 24.0 percent of the variance in relationship quality of young adults. The $Q^{2}$ value 0.188 for $R Q$ was larger than 0 (Hair et al., 2014) suggesting that all exogenous values in the model hold predictive ability over the endogenous variable. attitude towards divorce (ATTD, $f=0.117$ ) had a small effect size on relationship quality and parental divorce (PD, $f=0.007)$ was found to have no effect size on relationship quality.

\section{Discussion}

The current study examined the indirect pathways through which parental divorce was linked to a young adult's romantic relationship quality. Drawn from the perspectives of social learning theory and existing literature, we hypothesized that parental divorce would be linked to young adult's romantic relationship quality through attitude towards divorce. Results from PLS-SEM supported the hypothesis.

The association between parental divorce and romantic relationship quality of young adults was mediated by favorable attitudes towards divorce. This finding is consistent with conclusions derived from earlier studies exploring the mediation effect of attitude towards divorce on the association between parental divorce and romantic relationship qualities (Cui \& Fincham, 2010; Jacquet \& Surra, 2001; Riggio \& Fite, 2006). Specifically, parental divorce 
was related to more favorable attitudes towards divorce, which then was related to lower overall romantic relationship quality of young adults. Thus, the findings also supported the perspectives of Bandura's Social Learning Theory, which encompasses the lasting effects of learning through observation and modeling through family interactions.

Furthermore, this study has drawn-out the mediation effect of attitudes towards divorce on the relationship between parental divorce and single aspects of romantic relationship quality (e.g. commitment) to the association between parental divorce and overall relationship quality using commitment, love, satisfaction, intimacy, passion, and trust to reflect relationship quality. Social learning theory states that children form attitudes through their experiences and observations (Bandura, 1977). This finding is a reflection of the learning process whereby, young Maldivian adults have formed favorable attitudes towards divorce through their experiences of parental divorce and how it in turn is affecting their relationships.

Due to the alarming number of divorces in the Maldives, and the number of documented past studies establishing a negative direct effect of divorce on the relationship quality of young adults, we did not find the need to focus on the direct relationships between these variables. However, it was surprising to find that parental divorce was not directly associated with the relationship quality of young adults. These findings contradict the findings of previous research, where parental divorce has been negatively associated with young adults' romantic relationship quality (Amato \& Booth, 1991; Lee, 2018). However, Mahl (2001), has found that parental divorce by itself does not have to be negative. He suggests that it is important to look at pre-divorce factors such as interparental conflict that may contribute to the relationship between parental divorce and romantic relationship quality. The result of this study demonstrates a need to further explore the pre-divorce factors that may contribute to the quality of the romantic relationship of offsprings in the Maldives.

\section{Conclusions}

Despite the limitations, this study built on and extended the previous research to identify the mechanisms of how parental divorce impacts romantic relationship quality. The findings suggest that parental divorce was associated with low romantic relationship quality, through favorable attitudes towards divorce. The specific link, connecting parental divorce and relationship quality identified in this study will be helpful for professionals as it can be used to identify specific preventive measures to reduce the negative impact of parental divorce.

When interpreting the results of this study, several limitations should be considered. First, the generalizability of the findings is limited to university students, as our sample consisted only of university students enrolled in a degree program in the Maldives. The present study also had a huge imbalance of gender, $(76.2 \%)$ females and $(23.8 \%)$ males, in the sample. Future research needs to incorporate a larger sample with participants that are more representative of the general population in terms of gender and working population of the age group. 


\section{References}

Adamczyk, K. (2017). Voluntary and Involuntary Singlehood and Young Adults' Mental Health: an Investigation of Mediating Role of Romantic Loneliness. Current Psychology, 36(4), 888-904. doi:10.1007/s12144-016-9478-3

Amato, P. R. (1996). Explaining the Intergenerational Transmission of Divorce. Journal of Marriage and the Family, 58(3), 628. doi:10.2307/353723

Amato, P. R., \& Booth, A. (1991). Consequences of Parental Divorce and Marital Unhappiness for Adult Well-Being. Social Forces, 69(3), 895-914. doi:10.1093/sf/69.3.895

Amato, P. R., \& Kane, J. B. (2011). Parents' Marital Distress, Divorce, and Remarriage: Links with Daughters' Early Family Formation Transitions. Journal of Family Issues(8), 10731103. doi:10.1177/0192513X11404363

Bandura, A. (1977). Social learning theory. Englewood Cliffs, N.J.: Englewood Cliffs, N.J. : Prentice Hall.

Bartell, D. S. (2005). Influence of parental divorce on romantic relationships in young adulthood: A cognitive-developmental perspective. . In M. A. Fine \& J. H. Harvey (Eds.), Handbook of Divorce and Relationship Dissolution. London, United Kingdom: Taylor \& Francis Group.

Braithwaite, S. R., Doxey, R. A., Dowdle, K. K., \& Fincham, F. D. (2016). The Unique Influences of Parental Divorce and Parental Conflict on Emerging Adults in Romantic Relationships. Journal of Adult Development, 23(4), 214-225. doi:10.1007/s10804016-9237-6

Conger, R. D., Cui, M., Bryant, C. M., \& Elder, G. H. (2000). Competence in Early Adult Romantic Relationships: A Developmental Perspective on Family Influences. Journal of Personality and Social Psychology, 79(2), 224-237. doi:10.1037/0022-3514.79.2.224

Cui, M., \& Fincham, F. D. (2010). The differential effects of parental divorce and marital conflict on young adult romantic relationships. Personal Relationships, 17(3), 331-343. doi:10.1111/j.1475-6811.2010.01279.x

Cui, M., Fincham, F. D., \& Durtschi, J. A. (2011). The effect of parental divorce on young adults' romantic relationship dissolution: What makes a difference? Personal Relationships, 18(3), 410-426. doi:10.1111/j.1475-6811.2010.01306.x

Cunningham, M., \& Thornton, A. (2006). The Influences of Parents' and Offsprings' Experience with Cohabitation, Marriage, and Divorce on Attitudes Toward Divorce in Young Adulthood. Journal of Divorce \& Remarriage, 44(1-2), 119-144. doi:10.1300/J087v44n01_07

Diamantopoulos, A., \& Siguaw, J. A. (2006). Formative Versus Reflective Indicators in Organizational Measure Development: A Comparison and Empirical Illustration. British Journal of Management, 17(4), 263-282. doi:10.1111/j.14678551.2006.00500.x

Emery, R. E. (1999). Marriage, Divorce, and Children's Adjustment: SAGE Publications.

Fletcher, G. J. O., Simpson, J. A., \& Thomas, G. (2000). The Measurement of Perceived Relationship Quality Components: A Confirmatory Factor Analytic Approach. Personality and Social Psychology Bulletin, 26(3), 340-354. doi:10.1177/0146167200265007

Fornell, C., \& Larcker, D. (1981). Evaluating Structural Equation Models with Unobservable Variables and Measurement Error. Journal of Marketing Research, 18(1), 39. doi:10.2307/3151312 
Gray, L., \& Tallman, I. (1986). Predicting Choices in Asymptotic Decisions: A Comparison of Two Models. Social Psychology Quarterly, 49(2), 201. doi:10.2307/2786730

Hair, J., Sarstedt, M., Hopkins, L., \& Kuppelwieser, V. (2014). Partial Least Squares Structural Equation Modeling (PLS-SEM): An Emerging Tool for Business Research. European Business Review, 26, 106-121. doi:10.1108/EBR-10-2013-0128

Henseler, J., Ringle, C. M., \& Sarstedt, M. (2015). A new criterion for assessing discriminant validity in variance-based structural equation modeling. Journal of the Academy of Marketing Science, 43(1), 115-135. doi:10.1007/s11747-014-0403-8

Highest divorce rate (2002).

Retrieved from https://www.guinnessworldrecords.com/world-records/highestdivorce-

rate\#: :text=According\%20to\%20the\%20UN\%2C\%20the,the\%20United\%20States\%2 Owih\%204.34.

Jacquet, S. E., \& Surra, C. A. (2001). Parental Divorce and Premarital Couples: Commitment and Other Relationship Characteristics. Journal of Marriage and Family, 63(3), 627638. doi:10.1111/j.1741-3737.2001.00627.x

Kinnaird, K., \& Gerrard, M. (1986). Premarital sexual behavior and attitudes towards marriage and divorce among young women as a function of their mothers' marital status. Journal of Marriage and the Family, 48(4), 757. doi:10.2307/352568

Kumar, S., \& Mattanah, J. (2018). Interparental conflict, parental intrusiveness, and interpersonal functioning in emerging adulthood. Personal Relationships, 25(1), 120133. doi:10.1111/pere.12231

Kwan, L. L.Y., Mellor, D., Rizzuto, L., Kolar, C., \& Bt. Mamat, N. H. (2013). The Relationship Between Perceived Interparental Conflict and Malaysian Young Adults' Attitudes Toward Divorce. Journal of Divorce \& Remarriage, 54(7), 596-607. doi:10.1080/10502556.2013.828989

Lee, S. (2018). Parental Divorce, Relationships with Fathers and Mothers, and Children's Romantic Relationships in Young Adulthood. J. Adult Dev., 25(2), 121-134. doi:10.1007/s10804-017-9279-4

Lee, S. (2019). Romantic Relationships in Young Adulthood: Parental Divorce, Parent-child Relationships during Adolescence, and Gender.J Child Fam Stud 28, 411-423. https://doi.org/10.1007/s10826-018-1284-0

Mahl, D. (2001). The Influence of Parental Divorce on the Romantic Relationship Beliefs of Young Adults. Journal of Divorce \& Remarriage, 34(3-4), 89-118. doi:10.1300/J087v34n03_06

McLeod, S.A. (2019). Likert scale. Simply Psychology. Retrieved from https://www.somplypsychology.org/likert-scale.html.

Meier, A., \& Allen, G. (2008). Intimate relationship development during the transition to adulthood: Differences by social class. New Directions for Child and Adolescent Development, 2008(119), 25-39. doi:10.1002/cd.207

Moon, M. (2011). The Effects of Divorce on Children: Married and Divorced Parents' Perspectives. Journal of Divorce \&amp; Remarriage, 52(5), 344-349. doi:10.1080/10502556.2011.585093

Morrison, S. C., Fife, S. T., \& Hertlein, K. M. (2017). Mechanisms behind Prolonged Effects of Parental Divorce: A Phenomenological Study. Journal of Divorce \& Remarriage, 58(1), 44-63. doi:10.1080/10502556.2016.1262652 
Mustonen, U., Huurre, T., Kiviruusu, O., Haukkala, A., \& Aro, H. (2011). Long-Term Impact of Parental Divorce on Intimate Relationship Quality in Adulthood and the Mediating Role of Psychosocial Resources. Journal of Family Psychology, 25(4), 615-619. doi:10.1037/a0023996

Rholes, W., Simpson, J., Campbell, L., \& Grich, J. (2001). Adult attachment and the transition to parenthood. Journal of Personality and Social Psychology, 81(3), 421-435. doi:10.1037//0022-3514.81.3.421

Riggio, H. R., \& Fite, J. E. (2006). Attitudes toward divorce: embeddedness and outcomes in personal relationships. Journal of Applied Social Psychology, 36(12), 2935.

Riggio, H. R., \& Weiser, D. A. (2008). Attitudes toward marriage: Embeddedness and outcomes in personal relationships. Personal Relationships, 15(1), 123-140. doi:10.1111/j.14756811.2007.00188.x

Shansky, J. (2002). Negative effects of divorce on child and adolescent psychosocial adjustment. Journal of Pastoral Counseling, 37, 73-87.

Statistical Pocketbook-2017. (2017). Retrieved from http://statisticsmaldives.gov.mv/spb2017/

Whitton, S. W., Stanley, S. M., Markman, H. J., \& Johnson, C. A. (2013). Attitudes Toward Divorce, Commitment, and Divorce Proneness in First Marriages and Remarriages. Journal of Marriage and Family, 75(2), 276-287. doi:10.1111/jomf.12008

Yu, R., Branje, S., Keijsers, L., \& Meeus, W. (2015). Associations between young adult romantic relationship quality and problem behaviors: An examination of personalityenvironment interactions. Journal of Research in Personality, 57(9), 1-10. doi:10.1016/j.jrp.2015.01.003 